\title{
Histórias sobre aborto e infanticídio no século XX
}

\author{
Práticas proibidas: práticas \\ costumeiras de aborto e \\ infanticídio no século XX.
}

PEDRO, Joana Maria (Org.).

Florianópolis: Cidade Futura, 2003. $312 \mathrm{p}$.

\begin{abstract}
Casos como estes - de práticas de aborto e infanticídio - foram, e continuam a ser, encontrados no século XX; registrados em ocorrências policiais, em notícias de jornal e em processos judiciais (p. 20).
\end{abstract}

Essas palavras nos convidam a adentrar nos textos do livro organizado por Joana Maria Pedro Práticas proibidas: práticas costumeiras de aborto e infanticídio no século $X X$. Sem sombra de dúvida, o aborto e o infanticídio são temas polêmicos, uma vez que colocam questões éticas e morais importantes diante do que consideramos direitos humanos e controle sobre o próprio corpo. Os textos que compõem o livro analisam o conjunto dos discursos que se engendram e que constroem concepções acerca das práticas femininas. São diversas vozes que se manifestam, compondo um campo em que se constituem os caminhos trilhados pelas mulheres.

Cristiani, Núcia, Roselane, Eliana, Luciana, Maria Conceição, Maristela, Aniele e Vanderlei, coordenadas/os por Joana Pedro, mostram como se construíram ao longo do tempo as ações, as tentativas de controle, os discursos de criminalização, as penas para as condenadas, enfim, a publicização em torno do corpo feminino, interpretando e discutindo fontes variadas de pesquisa.

Nesse livro o/a leitor/a irá encontrar uma profusão de discursos a respeito da imagem da mulher, em que as/os autoras/es tentaram vislumbrar os meandros dos discursos que imprimiam a culpabilidade às mulheres que praticavam atos como aborto e infanticídio em Desterro/Florianópolis. E essas mulheres passavam, a partir desses atos, a ser alvo de intensos debates, seja na imprensa, nos discursos judiciários ou mesmo em toda a sociedade.

As narrativas contidas no livro revelam algumas histórias das mulheres que viviam na Florianópolis do início do século XX, mostrando suas resistências, seus amores, os relacionamentos entre os vizinhos, a família, as trajetórias, enfim, apresentam ao leitor as situações e as relações que estão presentes na discussão sobre aborto e infanticídio. Os 12 capítulos trazem múltiplos olhares sobre essas práticas. Os amores e dores, a passagem dos processos judiciários, as experiências, os silêncios, a autonomia do corpo feminino, a publicização das imagens femininas, - debate na imprensa são enunciados elaborados e reelaborados pelas/os autoras/es, que se preocuparam em mostrar as realidades vivenciadas no cotidiano da cidade.

A leitura desperta o interesse sobre como as práticas costumeiras de aborto e infanticídio foram discutidas e criminalizadas no passado, quando temos uma imagem de que seriam temas próprios apenas do momento atual. A 
representação dada a essas práticas atravessa - tempo, e ainda na contemporaneidade consegue nos fazer refletir sobre o corpo, o nosso corpo, o corpo das mulheres que praticaram esses atos.

O capítulo I, "Aborto e infanticídio: práticas muito antigas", aponta como se construíram, nos períodos históricos, a criminalização das práticas de aborto e infanticídio, principalmente com a atuação do poder público e também da Igreja Católica, os quais fomentavam os discursos sobre a valorização dos preceitos da moral.

O capítulo II, "Amores e dores, brigas e intrigas de Zulmas, Marizas, Florências...: processos judiciais", mostra a história das rés envolvidas com infanticídio e aborto, em que o agrupamento de vários depoimentos - das rés, dos namorados, dos maridos, dos vizinhos, dos parentes, dos advogados - compõe o cenário para a análise das condutas das mulheres que praticavam o aborto e o infanticídio. Os personagens exprimiam seus pontos de vista, acusando, indicando o erro, pregando uma punição, e assim se constituíam os discursos negativos para os atos das mulheres, apontandoas como culpadas.

O terceiro capítulo, "Aborto e infanticídio nos códigos penais e nos processos judiciais: a pedagogia de condutas femininas", destaca as mudanças na legislação brasileira, mostrando como os aparatos jurídico e médico inseriram novas formas de controle do corpo feminino. Assim, o corpo das mulheres, que permanecia quase sempre em silêncio, ganhava espaço nos códigos penais, e, das profundezas do olhar e do desejo, seus segredos mais íntimos passaram a ser avaliados.

Em relação ao controle do corpo, o quarto capítulo, "Um outro olhar sobre o corpo e práticas femininas: medicalização do aborto e infanticídio na cidade de Florianópolis", apresenta a introdução do conhecimento médico e de que forma a construção do saber especializado interferiu nos processos de criminalização do aborto e do infanticídio. As autoras aprofundam a discussão sobre os discursos que forjaram a constituição dos sujeitos e de suas práticas, criminosas ou não. Elaboram-se os saberes sobre - corpo da mulher, o qual passa a ser esquadrinhado, avaliado, medido e do qual se obtêm todas as informações sobre os atos de aborto e infanticídio.

O capítulo V, "O infanticídio na imprensa de Florianópolis..", descortina a publicização da imagem da mulher nos jornais locais e nacionais, tentando mostrar que o estranhamento em relação a essas práticas é construído socialmente e que o jornal serviu como um veículo para a qualificação ou (des)qualificação das mulheres. $\mathrm{Na}$ divulgação dos jornais, percebe-se a construção de uma imagem de mulher: a mãe dedicada, a esposa comportada, as moças que seguem as regras de conduta. Ainda hoje, o corpo feminino, silencioso e dissecado, continua sendo o principal suporte da publicidade. ${ }^{1}$

Já no capítulo VI, "Mulheres, memórias e experiências...", as autoras mostram as 'vozes' das mulheres, trazendo as práticas que não foram alvo de debates na imprensa, mas em que essas mulheres, a maioria com mais de 65 anos de idade, moradoras de Florianópolis, evidenciaram as estratégias femininas de autonomia e as resistências ao controle cotidiano sobre seu corpo. Assim, falar do corpo, dos partos, menstruação, aborto, trocar remédios só era possível nas redes de relações das mulheres. As comadres, as vizinhas, todas casadas, detinham um saber sobre o corpo feminino e, através do uso de chás, de banhos descortinavam um mundo de práticas desconhecidas pelos 'saberes científicos'.

Os capítulos VII, "A repercussão das disputas legislativas: a legislação sobre o aborto na imprensa", e VIII, "A prática do aborto sobre falas autorizadas: seus usos e abusos na mídia impressa brasileira", permitem que o/a leitor/a acompanhe as mudanças em relação à legislação: de duras penas aplicadas às mulheres até estratégias utilizadas para que algumas fossem absolvidas. Além disso, nesses capítulos são apontados os caminhos e os argumentos, na legislação e na imprensa, a favor e contra a criminalização do aborto.

O capítulo IX, "Corpos femininos em debate: aborto e infanticídio na imprensa de Florianópolis, uma história de controle e normatização", o capítulo X, "Uma história de notícias: o debate sobre o aborto em jornais e revistas", e o capítulo $\mathrm{XI}$, "Com a palavra, os leitores...", trazem a profusão de imagens e discursos proferidos pela mídia focalizando a historicidade dos debates sobre o aborto, em que se buscava um controle da autonomia do corpo feminino em um tom moralizador e normatizador. Os discursos amparados pela medicina ganharam relevância com a discussão política, tornando visível e dizível ações e práticas das mulheres. A imprensa, segundo as autoras, ocuparia um espaço de fórum debatedor, orientando a opinião pública sobre o aborto. Entram em cena os argumentos favoráveis e os contra à prática do aborto, em que todos os setores da sociedade são 
convidados a opinar sobre a ação da mulher. Esses capítulos mostram que a voz das mulheres era silenciada em meio à profusão de discursos, opiniões, debates.

Esse silêncio foi problematizado no capítulo XII, "Em silêncio... as mulheres que decidam", no qual é apresentado como se dão o processo de disciplina e as tentativas de controle da sexualidade e do corpo da mulher, mas ao mesmo tempo mostra que muitas mulheres desafiaram as políticas de controle, mantendo suas práticas costumeiras. Porém, a decisão do aborto e a culpa ficavam restritas às mulheres, sendo que ninguém queria discutir ou registrar isso. Logo, quando os discursos destacam o aborto como "coisas de mulher" atinentes ao campo privado, contribuem durante muito tempo para que o aborto não seja desnaturalizado.

A discussão sobre a desnaturalização, as penas e os debates em torno do assunto fecham o último capítulo, mas não fecham a problematização a respeito do aborto e do infanticídio. Nesse capítulo destaca-se que a visibilidade das práticas de aborto e infanticídio permite que se faça uma reflexão sobre o direito ao corpo, a descriminalização do aborto, o direito ao prazer, sendo impossível ignorar as questões em relação ao corpo feminino.

Em suma, o livro apresenta uma leitura histórica, e feminista, das práticas costumeiras de aborto e infanticídio em Santa Catarina. Histórica porque mostra essas práticas em sua construção, em meio aos debates que estiveram conformando os discursos e as ações dos personagens: das mulheres, dos juízes, das testemunhas, dos homens que seriam pais, das parteiras, dos médicos. Feminista porque assume claramente uma postura de desconstrução dos estereótipos relacionados ao tema do aborto e do infanticídio. Após a leitura, com certeza o/a leitor/a vai 'olhar' essas práticas de forma diferente.

' PERROT, Michele. "Os silêncios do corpo da mulher". In: MATOS, Maria Izilda S.; SOIHET, Raquel (Org.). O corpo feminino em debate. São Paulo: Editora da UNESP, 2003. p. 15.

Jaqueline Aparecida M. Zarbato Schmitt Universidade Federal de Santa Catarina 